\title{
ANALISIS SISTEM DAN PROSEDUR PENGHAPUSAN BARANG MILIK NEGARA PADA KANTOR WILAYAH KEMENTERIAN AGAMA PROVINSI SULAWESI UTARA
}

\author{
Indah Namira Kiay Demak ${ }^{1}$, Hendrik Manossoh ${ }^{2}$, Dhullo Afandi ${ }^{3}$ \\ ${ }^{1,2,3}$ Jurusan Akuntansi, Fakultas Ekonomi dan Bisnis, Universitas Sam Ratulangi, Jl. Kampus Bahu, Manado, \\ 95115, Indonesia
}

E-mail : indahnamirakd@yahoo.com

\begin{abstract}
State goods are all goods purchased or obtained at the expense of the State Revenue and Expenditure Budget or derived from other legitimate acquisitions. Elimination of state property is the final activity of the implementation of the management of state property and is an act that is not simple for government agencies. The publication of decisions on the abolition of state property occurs through procedures that are often seen as complicated and time consuming. This study aims to determine whether the system and procedures for the elimination of State Property at the Regional Office of the Ministry of Religious Affairs of North Sulawesi Province has been in accordance with Regulation of the Minister of Finance No. 83 / PMK.06 / 2016 on the Procedures for the Implementation of Destruction and Elimination of State Property, as seen from or not fulfillment of elements of internal control system of government according to Government Regulation Number 60 Year 2008 regarding Government Internal Control System. The research method used in this thesis research is descriptive method whose purpose each data collected, analyzed, then drawn a conclusion and the type of research used is qualitative descriptive. The results of this study concluded that the system and procedures for the elimination of state property in the Regional Office of the Ministry of Religious Affairs of North Sulawesi Province have been in accordance with the Regulation of the Minister of Finance No. 83 / PMK.06 / 2016 on the Procedures for Implementation of Destruction and Elimination of State Property, and has fulfilled the elements of the internal control system of government according to Government Regulation Number 60 Year 2008 regarding Government Internal Control System.
\end{abstract}

Keywords: Analysis, Systems and Procedures, Elimination of State Property.

\section{PENDAHULUAN}

Indonesia memiliki beragam instansi pemerintah dengan tugas dan wewenang masing-masing. Kementerian/Lembaga Negara dalam menjalankan tugas dan fungsi organisasi membutuhkan berbagai sarana dan prasarana yang memadai yang terkelola dengan baik dan efisien untuk menunjang pelayanan kepada masyarakat. Hal ini sejalan dengan ketentuan yang diatur dalam Undang-Undang Nomor 17 Tahun 2003 tentang Keuangan Negara bahwa Menteri Keuangan sebagai pembantu Presiden dalam bidang Keuangan Negara bertindak sebagai Chief Financial Officer (CFO) Pemerintah Republik Indonesia yang berwenang dan bertanggungjawab atas pengelolaan aset dan kewajiban negara secara nasional. Undang-Undang Nomor 17 Tahun 2003 tentang Keuangan Negara menyatakan bahwa keuangan negara adalah semua hak dan kewajiban negara yang dapat dinilai dengan uang, serta segala sesuatu baik berupa uang maupun berupa barang yang dapat dijadikan milik negara berhubung dengan pelaksanaan hak dan kewajiban tersebut.

Kewenangan dan tanggung jawab Menteri Keuangan dalam pengelolaan aset negara dituangkan dalam Peraturan Pemerintah Nomor 27 Tahun 2014 tentang Pengelolaan Barang Milik Negara/Daerah. Berdasarkan Peraturan Pemerintah Nomor 27 Tahun 2014 tentang 
Pengelolaan Barang Milik Negara/Daerah, yang dimaksud dengan Barang Milik Negara adalah semua barang yang dibeli atau diperoleh atas beban Anggaran Pendapatan dan Belanja Negara atau berasal dari perolehan lainnya yang sah. Dalam akuntansi pemerintahan, Barang Milik Negara merupakan bagian dari aset pemerintah pusat yang berwujud.

Penghapusan Barang Milik Negara merupakan kegiatan akhir dari pelaksanaan pengelolaan Barang Milik Negara. Berdasarkan Peraturan Pemerintah Nomor 27 Tahun 2014 tentang Pengelolaan Barang Milik Negara/Daerah, penghapusan Barang Milik Negara adalah tindakan menghapus Barang Milik Negara dari daftar barang dengan menerbitkan keputusan dari pejabat yang berwenang untuk membebaskan Pengguna Barang dan/atau Kuasa Pengguna Barang dan/atau Pengelola Barang dari tanggung jawab administrasi dan fisik atas barang yang berada dalam penguasaannya. Penghapusan Barang Milik Negara merupakan suatu tindakan yang tidak sederhana bagi instansi pemerintah.

Terbitnya keputusan penghapusan Barang Milik Negara terjadi melalui prosedur yang sering kali dipandang rumit dan memakan waktu yang cukup lama. Apabila terdapat barang yang sudah tidak dapat digunakan atau bahkan tidak lagi memberikan kontribusi terhadap kegiatan operasional dalam bekerjanya pemerintahan namun belum dilakukan suatu tindakan penghapusan, maka akan berdampak terhadap bertambahnya biaya pemeliharaan atas Barang Milik Negara tersebut. Mengingat dampaknya yang begitu penting, penghapusan Barang Milik Negara tersebut harus didasari oleh sebuah keputusan resmi dari pejabat yang berwenang dan dilaksanakan mengacu pada Peraturan Pemerintah yang berlaku. Tata cara pelaksanaan penghapusan Barang Milik Negara diatur lebih lanjut di dalam Peraturan Menteri Keuangan Nomor 83/PMK.06/2016 tentang Tata Cara Pelaksanaan Pemusnahan dan Penghapusan Barang Milik Negara.

\section{TINJAUAN PUSTAKA}

\subsection{Akuntansi Pemerintahan}

Bastian (2010:6) mengutarakan bahwa akuntansi pemerintahan merupakan alat untuk menganalisis akuntansi yang dijalankan untuk mengelola dana masyarakat di lembagalembaga tinggi negara serta departemen-departemen dibawahnya, pemerintah daerah, Badan Usaha Milik Negara (BUMN), Badan Usaha Milik Daerah (BUMD), Lembaga Swadaya Masyarakat (LSM) dan yayasan sosial pada proyek-proyek kerja sama sektor publik dan swasta khususnya pada tahapan pelaksanaan anggaran, termasuk segala pengaruh yang terjadi, bersifat seketika maupun yang lebih permanen pada semua tingkatan dan unit pemerintahan.

\subsubsection{Standar Akuntansi Pemerintahan}

Peraturan Pemerintah Nomor 71 Tahun 2010 tentang Standar Akuntansi Pemerintahan sebagai pengganti Peraturan Pemerintah Nomor 24 Tahun 2005. Peraturan Pemerintah Nomor 71 Tahun 2010 Pasal 1 ayat (3) tentang Standar Akuntansi Pemerintahan menyatakan bahwa Standar Akuntansi Pemerintahan adalah prinsip-prinsip akuntansi yang diterapkan dalam menyusun dan menyajikan laporan keuangan pemerintahan.

\subsubsection{Standar Akuntansi Pemerintahan Berbasis Akrual}

Peraturan Pemerintah Nomor 71 Tahun 2010 Pasal 1 ayat (8) menyatakan bahwa standar akuntansi pemerintahan berbasis akrual adalah standar akuntansi pemerintahan yang mengakui pendapatan, beban, aset, utang dan ekuitas dalam laporan finansial, dan mengakui pendapatan, belanja serta pembiayaan dalam pelaksanaan anggaran berdasarkan basis yang ditetapkan dalam APBN/APBD. Dalam Pernyataan Nomor 01 Standar Akuntansi Pemerintahan Berbasis Akrual menyatakan bahwa basis akrual adalah basis akuntansi yang mengakui pengaruh transaksi dan peristiwa lainnya pada saat transaksi dan peristiwa itu terjadi. 


\subsection{Sistem Pengendalian Intern}

Sebagaimana diatur dalam Peraturan Pemerintah Nomor 60 Tahun 2008 yang menyatakan bahwa sistem pengendalian intern adalah kegiatan yang dilakukan secara berkelanjutan oleh pimpinan dan seluruh pegawai untuk memberikan keyakinan memadai atas tercapainya tujuan organisasi melalui aktivitas yang efektif dan efisien, keandalan laporan keuangan, pengamanan aset negara, dan ketaatan terhadap peraturan perundangundangan.

\subsubsection{Tujuan Sistem Pengendalian Intern}

Dalam teori Mulyadi (2013:163) dinyatakan bahwa tujuan sistem pengendalian intern adalah untuk menjaga kekayaan dan catatan organisasi, mengecek ketelitian dan keandalan akuntansi, mendorong efisiensi, serta mendorong dipatuhinya kebijakan manajemen.

\subsubsection{Unsur-Unsur Sistem Pengendalian Intern}

Peraturan Pemerintah Nomor 60 Tahun 2008 tentang Sistem Pengendalian Intern Pemerintah memperkenalkan adanya 5 (lima) unsur sistem pengendalian intern pemerintah, meliputi:

1. Lingkungan Pengendalian

Penerapan sistem pengendalian intern dalam lingkungan kerja harus dapat menimbulkan perilaku positif dan kondusif dengan cara menciptakan dan memelihara lingkungan pengendalian.

2. Penilaian Risiko

Pimpinan instansi pemerintah wajib melakukan penilaian risiko. Penilaian risiko terdiri atas identifikasi risiko dan analisis risiko.

3. Kegiatan Pengendalian

Kegiatan pengendalian wajib diselenggarakan sesuai dengan ukuran, kompleksitas, dan sifat dari tugas dan fungsi instansi pemerintah yang bersangkutan.

4. Informasi dan Komunikasi

wajib diidentifikasi, dicatat, dan dikomunikasikan dalam bentuk dan waktu yang tepat oleh pimpinan instansi pemerintah dan komunikasi atas informasi wajib diselenggarakan secara efektif.

5. Pemantauan

Pemantauan dilakukan secara berkelanjutan, dievaluasi dengan cara terpisah, dan menindaklanjuti rekomendasi hasil audit dan reviu lainnya.

\subsection{Standar Operasional Prosedur (SOP)}

Standar Operasional Prosedur (SOP) terdiri dari serangkaian instruksi yang menggambarkan pendokumentasian dari kegiatan yang dilakukan secara berulang pada suatu organisasi maupun instansi pemerintahan, dimana pekerjaan tersebut dilakukan, berhubungan dengan apa yang dilakukan, bagaimana melakukannya, bilamana melakukannya, di mana melakukannya, dan siapa yang melakukannya (Moekijat, 2008) dan Sailendra (2015:11) menyatakan bahwa SOP merupakan panduan yang digunakan untuk memastikan kegiatan operasional organisasi atau perusahaan berjalan dengan lancar.

\subsection{Barang Milik Negara}

Berdasarkan Peraturan Pemerintah Nomor 27 Tahun 2014 tentang Pengelolaan Barang Milik Negara/Daerah yang dimaksud dengan Barang Milik Negara adalah semua barang yang dibeli atau diperoleh atas beban Anggaran Pendapatan dan Belanja Negara atau berasal dari perolehan lainnya yang sah. Barang yang berasal dari perolehan lainnya yang sah.

\subsubsection{Penghapusan Barang Milik Negara}

Kegiatan penghapusan Barang Milik Negara merupakan tindakan untuk meniadakan Barang Milik Negara dari daftar barang dengan menerbitkan keputusan dari pejabat yang berwenang untuk membebaskan Pengelola Barang, Pengguna Barang, dan/atau Kuasa 
Pengguna Barang dari pertanggungjawaban administrasi dan fisik atas barang yang berada dalam penguasaannya. Keputusan dari pejabat yang berwenang sebagaimana dimaksud dalam definisi penghapusan Barang Milik Negara yaitu berupa keputusan penghapusan Barang Milik Negara yang ditetapkan oleh:

a. Menteri Keuangan selaku Pengelola Barang Milik Negara yang status penggunaannya berada pada Pengelola Barang;

b. Menteri/Pimpinan Lembaga selaku Pengguna Barang Milik Negara yang status penggunaannya berada pada Pengguna Barang setelah mendapat persetujuan dari Pengelola Barang.

\subsubsection{Tata Cara Pelaksanaan Penghapusan Barang Milik Negara}

Berdasarkan Peraturan Menteri Keuangan Nomor 83/PMK.06/2016, tata cara pelaksanaan penghapusan Barang Milik Negara yang berada pada Pengguna barang adalah sebagai berikut:

a. Penyerahan Kepada Pengelola Barang;

b. Pengalihan Status Penggunaan Barang Milik Negara Kepada Pengguna Barang Lain;

c. Pemindahtanganan;

d. Adanya Putusan Pengadilan Yang Telah Memperoleh Kekuatan Hukum Tetap Serta Sudah Tidak Ada Upaya Hukum Lainnya;

e. Melaksanakan Ketentuan Peraturan Perundang-undangan;

f. Pemusnahan; dan

g. Sebab-Sebab Lain.

\subsection{Penelitian terdahulu}

Penelitian terdahulu yang penulis jadikan sebagai bahan pertimbangan dalam melakukan penelitian di Kantor Wilayah Kementerian Agama Provinsi Sulawesi Utara. Penelitian yang dilakukan oleh Annisa Robbi Rodliya tahun 2015, tentang Tinjauan atas sistem penghapusan aktiva tetap barang milik negara (BMN) pada Direktorat Sarana dan Prasarana Institut Teknologi Bandung, menyatakan bahwa Sistem penghapusan aktiva tetap Barang Milik Negara pada Direktorat Sarana dan Prasarana ITB mengalami hambatan dimana dalam melakukan penghapusan memerlukan waktu yang lama dan dianggap rumit karena pelaksanaannya dilakukan bersama dengan pihak lain yaitu Kantor Pelayanan Kekayaan Negara dan Lelang (KPKNL). Namun, sistem penghapusan tersebut telah sesuai dengan peraturan yang berlaku yaitu Peraturan Menteri Keuangan Nomor 50/PMK.06/2014 tentang Tata Cara Pelaksanaan Penghapusan Barang Milik Negara.

\section{METODE PENELITIAN}

\subsection{Jenis Penelitian}

Penelitian ini termasuk pada jenis penelitian deskriptif kualitatif dimana untuk menggambarkan atau menganalisis suatu hasil penelitian tetapi tidak digunakan untuk membuat kesimpulan yang lebih luas menurut Sugiyono (2014:22) dan Afrizal (2016:13) menyatakan bahwa penelitian kualitatif adalah metode penelitian ilmu-ilmu sosial yang mengumpulkan dan menganalisis data berupa kata-kata (lisan maupun tulisan) dan perbuatanperbuatan manusia serta penelitian tidak berusaha mengkalkulasi data kualitatif yang telah diperoleh. Jenis data yang digunakan dalam penelitian ini adalah data kualitatif yang merupakan kumpulan dari data non angka, yang bentuknya informasi baik lisan maupun tulisan, seperti gambaran umum, struktur organisasi, pembagian tugas dan fungsi, serta sistem dan prosedur penghapusan barang milik negara pada Kantor Wilayah Kementerian Agama Provinsi Sulawesi Utara. 


\subsection{Waktu dan Tempat Penelitian}

Penelitian ini dilaksanakan pada Kantor Wilayah Kementerian Agama Provinsi

Sulawesi Utara yang bertempat di Jl. 17 Agustus, Kota Manado, Sulawesi Utara. Waktu Penelitian dimulai dari Maret sampai dengan bulan April 2018.

\subsection{Metode Analisis}

Metode analisis yang digunakan dalam penelitian ini adalah sebagai berikut:

1. Mengumpulkan data-data dan keterangan-keterangan mengenai sistem dan prosedur Penghapusan Barang Milik Negara pada Kantor Wilayah Kementerian Agama Provinsi Sulawesi Utara.

2. Menganalisis mengenai fakta-fakta dengan membandingkan sistem dan prosedur Penghapusan Barang Milik Negara yang dilakukan oleh Kantor Wilayah Kementerian Agama Provinsi Sulawesi Utara dengan peraturan yang berlaku.

3. Berdasarkan hasil analisis ditarik kesimpulan dan diberikan beberapa saran yang dianggap perlu.

\section{HASIL ANALISIS DAN PEMBAHASAN}

4.1 Hasil analisis

4.1.1 Sistem dan Prosedur Penghapusan Barang Milik Negara

4.1.1.1 Sistem Penghapusan Barang Milik Negara

Dalam sistem penghapusan Barang Milik Negara, Kantor Wilayah Kementerian Agama Provinsi Sulawesi Utara memiliki diagram alir Standar Operasional Prosedur (SOP) penghapusan Barang Milik Negara.

\subsubsection{Prosedur Penghapusan Barang Milik Negara}

Terdapat beberapa prosedur yang harus dilaksanakan oleh Kantor Wilayah Kementerian Agama Provinsi Sulawesi Utara dalam melaksanakan penghapusan Barang Milik Negara, antara lain:

1. Pembentukan panitia penghapusan;

2. Pelaksanaan Opname Fisik Barang Inventaris (OFBI);

3. Pengajuan usul penghapusan kepada Kepala Kantor Wilayah Kementerian Agama Provinsi Sulawesi Utara;

4. Pengajuan permohonan penghapusan kepada Kementerian Keuangan;

5. Persetujuan/penolakan dari Kementerian Agama;

6. Pelaksanaan pelelangan penghapusan;

7. Penyetoran hasil lelang ke kas Negara; dan

8. Penghapusan barang dari daftar Barang Milik Negara.

\subsubsection{Sistem dan Prosedur Penghapusan Barang Milik Negara Dilihat Dari Unsur-} Unsur Sistem Pengendalian Intern Pemerintah

Adapun pengendalian intern atas sistem dan prosedur penghapusan Barang Milik Negara pada Kantor Wilayah Kementerian Agama Provinsi Sulawesi Utara dilihat dari unsurunsur sistem pengendalian intern pemerintah menurut Peraturan Pemerintah Nomor 60 Tahun 2008 tentang Sistem Pengendalian Intern Pemerintah adalah sebagai berikut:

1. Lingkungan Pengendalian

Penghapusan Barang Milik Negara pada Kantor Wilayah Kementerian Agama Provinsi Sulawesi Utara dilaksanakan oleh panitia penghapusan yaitu pegawai Bagian Tata Usaha yang ditunjuk oleh Kepala Kantor berdasarkan surat keputusan pembentukan panitia penghapusan yang mempunyai tugas untuk melaksanakan penghapusan Barang Milik Negara dimulai dari awal pengumpulan dokumen dan barang yang akan dihapus hingga melaporkan pelaksanaan tugas kepada Kepala Kantor selaku pemberi perintah. Pemberian perintah dari Kepala Kantor kepada pegawai Bagian Tata Usaha sebagai panitia penghapusan disebabkan karena salah satu tugas dan fungsi Bagian Tata Usaha 
adalah mengelola barang/kekayaan negara, sebagaimana yang tertera dalam Struktur Organisasi Kantor Wilayah Kementerian Agama Provinsi Sulawesi Utara yang mengacu pada Peraturan Menteri Agama Nomor 13 Tahun 2012 tentang Organisasi dan Tata Kerja Instansi Vertikal Kementerian Agama.

2. Penilaian Risiko

Risiko yang mungkin terjadi terkait dengan pelaksanaan penghapusan Barang Milik Negara adalah banyaknya prosedur yang harus dilalui yang berdampak pada lamanya waktu yang dibutuhkan hingga dihapuskannya Barang Milik Negara tersebut. Hal tersebut memakan waktu yang cukup lama karena proses otorisasi penghapusan Barang Milik Negara pada Kantor Wilayah Kementerian Agama Provinsi Sulawesi Utara harus mendapatkan persetujuan terlebih dahulu dari Kementerian Agama yang memerlukan waktu hingga 3 sampai 4 bulan yang disebabkan karena banyaknya satuan kerja Kementerian Agama yang juga melakukan koordinasi dengan Kementerian Agama. Kantor Wilayah Kementerian Agama Provinsi Sulawesi Utara dalam penghapusan Barang Milik Negara dilakukan sekaligus pada saat telah terkumpulnya beberapa barang yang telah memenuhi persyaratan penghapusan. Hal tersebut dilakukan agar terjadi efisiensi waktu dalam pelaksanaan penghapusan Barang Milik Negara yang proses otorisasinya memerlukan waktu yang cukup lama. Adapun risiko yang mungkin terjadi terkait dengan penghapusan barang dari daftar Barang Milik Negara adalah terjadinya kekeliruan atau kesalahan penginputan data SIMAK BMN oleh petugas. Oleh karena itu diperlukan ketelitian dalam melaksanakan penginputan data. Kantor Wilayah Kementerian Agama Provinsi Sulawesi Utara rutin mengikutsertakan pegawai yang bertugas sebagai petugas SIMAK BMN dalam kegiatan sosialisasi dan bimbingan teknis penggunaan aplikasi SIMAK BMN guna meminimalisir terjadinya kekeliruan atau kesalahan dalam penginputan data.

3. Kegiatan Pengendalian

Tanggung jawab pelaksanaan penghapusan Barang Milik Negara pada Kantor Wilayah Kementerian Agama Provinsi Sulawesi Utara dilimpahkan kepada pegawai Bagian Tata Usaha yang diberi perintah oleh Kepala Kantor sebagai panitia penghapusan. Hal tersebut tercantum dalam Standar Operasional Prosedur (SOP) Penghapusan Barang Milik Negara pada Kantor Wilayah Kementerian Agama Provinsi Sulawesi Utara.

4. Informasi dan Komunikasi

Informasi mengenai pelaksanaan penghapusan Barang Milik Negara telah diterima dengan baik oleh panitia penghapusan melalui keikutsertaan dalam kegiatan sosialisasi dan bimbingan teknis pengelolaan Barang Milik Negara, serta informasi mengenai penghapusan barang dari daftar Barang Milik Negara telah diterima dengan baik oleh petugas input data SIMAK BMN melalui keikutsertaan dalam kegiatan sosialisasi dan bimbingan teknis mengenai tata cara penggunaan aplikasi SIMAK BMN sehingga terciptalah komunikasi yang sejalan dan sesuai dengan yang diharapkan.

5. Pemantauan

Pemantauan terhadap pelaksanaan penghapusan Barang Milik Negara pada Kantor Wilayah Kementerian Agama Provinsi Sulawesi Utara dilaksanakan oleh Kepala Kantor selaku pimpinan. Pemantauan tersebut dilakukan dengan melihat dan mengevaluasi hasil pelaksanaan tugas yang dilaksanakan oleh panitia penghapusan, sebagaimana salah satu tugas panitia penghapusan yaitu melaporkan hasil pelaksanaan tugas kepada Kepala Kantor selaku pemberi perintah, serta melihat dan mengevaluasi Laporan Barang Milik Negara semesteran dan tahunan yang dihasilkan akibat penginputan data penghapusan Barang Milik Negara ke dalam aplikasi SIMAK BMN. 


\subsection{Pembahasan}

\subsubsection{Analisis Sistem dan Prosedur Penghapusan Barang Milik Negara}

\subsubsection{Analisis Sistem Penghapusan Barang Milik Negara}

Sistem penghapusan Barang Milik Negara pada Kantor Wilayah Kementerian Agama Provinsi Sulawesi Utara dilakukan dengan mengikuti diagram alir Standar Operasional Prosedur (SOP) penghapusan Barang Milik Negara yang dimiliki. Standar Operasional Prosedur (SOP) penghapusan Barang Milik Negara tersebut sudah sesuai dengan peraturan yang berlaku yaitu Peraturan Menteri Keuangan Nomor 83/PMK.06/2016 tentang Tata Cara Pelaksanaan Pemusnahan dan Penghapusan Barang Milik Negara, sebagaimana yang tercantum dalam Standar Operasional Prosedur (SOP) penghapusan Barang Milik Negara tersebut yang dimulai dari alur pembentukan panitia penghapusan, pelaksanaan Opname Fisik Barang Inventaris (OFBI), pengajuan usul penghapusan kepada Kepala Kantor Wilayah Kementerian Agama Provinsi Sulawesi Utara, pengajuan permohonan penghapusan kepada Kementerian Keuangan, persetujuan/penolakan dari Kementerian Agama, pelaksanaan pelelangan penghapusan, penyetoran hasil lelang ke kas negara, hingga dihapuskannya Barang Milik Negara tersebut dari Daftar Barang yang menghasilkan Laporan Barang Milik Negara semesteran dan tahunan.

\subsubsection{Analisis Prosedur Penghapusan Barang Milik Negara}

Berdasarkan penelitian yang dilaksanakan, pelaksanaan penghapusan Barang Milik Negara pada Kantor Wilayah Kementerian Agama Provinsi Sulawesi Utara sudah sesuai dengan peraturan yang berlaku yaitu Peraturan Menteri Keuangan Nomor 83/PMK.06/2016 tentang Tata Cara Pelaksanaan Pemusnahan dan Penghapusan Barang Milik Negara. Hal ini terlihat dari Standar Operasional Prosedur (SOP) Penghapusan Barang Milik Negara pada Kantor Wilayah Kementerian Agama Provinsi Sulawesi Utara yang dimana pelaksanaan penghapusan Barang Milik Negara dimulai dari alur pembentukan panitia penghapusan hingga dihapuskanlah Barang Milik Negara tersebut dari Daftar Barang Kuasa Pengguna setelah ditetapkannya keputusan Penghapusan Barang Milik Negara oleh Pengguna Barang setelah mendapat persetujuan Pengelola Barang.

Sebagaimana yang terdapat dalam Peraturan Menteri Keuangan Nomor 83/PMK.06/2016, bahwa Menteri/Pimpinan lembaga selaku Pengguna Barang memiliki kewenangan dan tanggung jawab dalam hal Penghapusan Barang Milik Negara, antara lain:

a. mengajukan permohonan Penghapusan Barang Milik Negara kepada Pengelola Barang;

b. menetapkan keputusan Penghapusan Barang Milik Negara yang status penggunaannya berada pada Pengguna Barang setelah mendapat persetujuan Pengelola Barang; dan

c. melaksanakan Penghapusan Barang Milik Negara yang status penggunaannya berada pada Pengguna Barang dari Daftar Barang Pengguna dan/atau Daftar Barang Kuasa Pengguna berdasarkan keputusan Penghapusan Barang Milik Negara.

Penghapusan barang dari Daftar Barang Milik Negara pada Kantor Wilayah Kementerian Agama Provinsi Sulawesi Utara juga sudah sesuai dengan peraturan yang berlaku yaitu Peraturan Menteri Keuangan Nomor 83/PMK.06/2016 tentang Tata Cara Pelaksanaan Pemusnahan dan Penghapusan Barang Milik Negara. Hal ini terlihat dari Standar Operasional Prosedur (SOP) penghapusan Barang Milik Negara pada Kantor Wilayah Kementerian Agama Provinsi Sulawesi Utara dalam hal pencatatan Barang Milik Negara yang telah dihapuskan yaitu terjadinya perubahan Daftar Barang pada Laporan Barang Milik Negara Semesteran dan Tahunan.

Sebagaimana yang terdapat dalam Peraturan Menteri Keuangan Nomor 83/PMK.06/2016 Bab III Pasal (39) yang menyatakan bahwa:

a. Perubahan Daftar Barang Pengguna dan/atau Daftar Barang Kuasa Pengguna sebagai akibat dari Penghapusan Barang Milik Negara karena Pemindahtanganan harus 
dicantumkan dalam Laporan Barang Pengguna dan/atau Laporan Barang Kuasa Pengguna Semesteran dan Tahunan.

b. Perubahan Daftar Barang Milik Negara sebagai akibat dari Penghapusan Barang Milik Negara karena Pemindahtanganan harus dicantumkan dalam Laporan Barang Milik Negara Semesteran dan Tahunan.

Selain pencatatan dalam Laporan Barang Milik Negara Semesteran dan Tahunan yang mengalami perubahan, terjadi pula perubahan data dalam aplikasi SIMAK BMN karena terjadinya Penghapusan Barang Milik Negara yang berdampak pada berkurangnya daftar inventarisasi Barang Milik Negara pada aplikasi tersebut.

\subsubsection{Analisis Sistem dan Prosedur Penghapusan Barang Milik Negara Dilihat Dari Unsur-Unsur Sistem Pengendalian Intern Pemerintah}

Berdasarkan penelitian yang dilaksanakan, sistem dan prosedur penghapusan Barang Milik Negara pada Kantor Wilayah Kementerian Agama Provinsi Sulawesi Utara telah memenuhi unsur-unsur sistem pengendalian intern pemerintah sesuai dengan peraturan yang berlaku yaitu Peraturan Pemerintah Nomor 60 Tahun 2008 tentang Sistem Pengendalian Intern Pemerintah. Hal tersebut dapat dilihat dari masing-masing unsur sistem pengendalian intern pemerintah atas sistem dan prosedur penghapusan Barang Milik Negara pada Kantor Wilayah Kementerian Agama Provinsi Sulawesi Utara yang telah memadai, antara lain:

1. Lingkungan Pengendalian

Dari segi lingkungkan pengendalian disebutkan bahwa pimpinan instansi pemerintah wajib menciptakan dan memelihara lingkungan pengendalian yang menimbulkan perilaku positif dan kondusif untuk penerapan sistem pengendalian intern dalam lingkungan kerjanya yaitu salah satunya melalui pembentukan struktur organisasi yang sesuai dengan kebutuhan. Hal ini jika dikaitkan dengan konsep sistem pengendalian intern pemerintah dari segi lingkungan pengendalian, maka dapat dikatakan bahwa sistem dan prosedur penghapusan Barang Milik Negara pada Kantor Wilayah Kementerian Agama Provinsi Sulawesi Utara telah memadai dilihat dari telah terpenuhinya salah satu faktor yang berpengaruh terhadap lingkungan pengendalian tersebut yaitu adanya struktur organisasi Kantor Wilayah Kementerian Agama Provinsi Sulawesi Utara yang mengacu pada Peraturan Menteri Agama Nomor 13 Tahun 2012 tentang Organisasi dan Tata Kerja Instansi Vertikal Kementerian Agama.

2. Penilaian Risiko

Dari segi penilaian risiko disebutkan bahwa pimpinan instansi pemerintah wajib melakukan penilaian risiko yang terdiri dari identifikasi risiko dan analisis risiko. Hal ini jika dikaitkan dengan konsep sistem pengendalian intern pemerintah dari segi penilaian risiko, maka dapat dikatakan bahwa sistem dan prosedur penghapusan Barang Milik Negara pada Kantor Wilayah Kementerian Agama Provinsi Sulawesi Utara telah memadai dilihat dari telah terpenuhinya faktor yang berpengaruh terhadap penilaian risiko tersebut yaitu adanya identifikasi risiko dan analisis risiko yang mungkin terjadi disertai dengan tindakan yang dilakukan untuk meminimalisir risiko yang mungkin terjadi.

3. Kegiatan Pengendalian

Dari segi kegiatan pengendalian disebutkan bahwa pimpinan instansi pemerintah wajib menyelenggarakan kegiatan pengendalian yang salah satunya memiliki karakteristik yaitu adanya kebijakan dan prosedur yang harus ditetapkan secara tertulis. Hal ini jika dikaitkan dengan konsep sistem pengendalian intern pemerintah dari segi kegiatan pengendalian, maka dapat dikatakan bahwa sistem dan prosedur penghapusan Barang Milik Negara pada Kantor Wilayah Kementerian Agama Provinsi Sulawesi Utara telah memadai dilihat dari telah terpenuhinya salah satu karakteristik yang berpengaruh 
terhadap kegiatan pengendalian tersebut yaitu adanya Standar Operasional Prosedur (SOP) penghapusan Barang Milik Negara yang dimiliki secara tertulis oleh Kantor Wilayah Kementerian Agama Provinsi Sulawesi Utara.

4. Informasi dan Komunikasi

Dari segi informasi dan komunikasi disebutkan bahwa pimpinan instansi pemerintah wajib mengkomunikasikan informasi dalam bentuk dan waktu yang tepat, serta diselenggarakan secara efektif yang salah satunya yaitu dengan menyediakan dan memanfaatkan berbagai bentuk dan sarana komunikasi. Hal ini jika dikaitkan dengan konsep sistem pengendalian intern pemerintah dari segi informasi dan komunikasi, maka dapat dikatakan bahwa sistem dan prosedur penghapusan Barang Milik Negara pada Kantor Wilayah Kementerian Agama Provinsi Sulawesi Utara telah memadai dilihat dari telah terpenuhinya salah satu bentuk penyelenggaraan yang berpengaruh terhadap informasi dan komunikasi tersebut, yaitu adanya keikutsertaan Bagian Tata Usaha dalam kegiatan sosialisasi dan bimbingan teknis pengelolaan Barang Milik Negara, serta tata cara penggunaan aplikasi SIMAK BMN.

5. Pemantauan

Dari segi pemantauan disebutkan bahwa pimpinan instansi pemerintah wajib melakukan pemantauan yang salah satunya yaitu dengan melakukan evaluasi. Hal ini jika dikaitkan dengan konsep sistem pengendalian intern pemerintah dari segi pemantauan, maka dapat dikatakan bahwa sistem dan prosedur penghapusan Barang Milik Negara pada Kantor Wilayah Kementerian Agama Provinsi Sulawesi Utara telah memadai dilihat dari telah terpenuhinya salah satu tindakan yang berpengaruh terhadap pemantauan tersebut, yaitu adanya pemantauan yang dilakukan oleh Kepala Kantor selaku pimpinan dengan mengevaluasi hasil pelaksanaan tugas yang dilaksanakan oleh panitia penghapusan, serta mengevaluasi Laporan Barang Milik Negara semesteran dan tahunan yang dihasilkan akibat penginputan data penghapusan Barang Milik Negara ke dalam aplikasi SIMAK BMN.

\section{KESIMPULAN DAN SARAN}

5.1. Kesimpulan

Berdasarkan hasil penelitian dan pembahasan yang telah dilaksanakan pada Kantor Wilayah Kementerian Agama Provinsi Sulawesi Utara dapat diambil kesimpulan sebagai berikut:

1. Sistem dan prosedur penghapusan Barang Milik Negara pada Kantor Wilayah Kementerian Agama Provinsi Sulawesi Utara sudah sesuai dengan Peraturan Menteri Keuangan Nomor 83/PMK.06/2016 tentang Tata Cara Pelaksanaan Pemusnahan dan Penghapusan Barang Milik Negara.

2. Sistem dan prosedur penghapusan Barang Milik Negara pada Kantor Wilayah Kementerian Agama Provinsi Sulawesi Utara telah memenuhi unsur-unsur sistem pengendalian intern pemerintah menurut Peraturan Pemerintah Nomor 60 Tahun 2008 tentang Sistem Pengendalian Intern Pemerintah.

3. Kantor Wilayah Kementerian Agama Provinsi Sulawesi Utara mengalami hambatan berupa diperlukannya waktu yang cukup lama dalam melaksanakan tindakan penghapusan Barang Milik Negara. Hal ini disebabkan karena proses otorisasi Penghapusan Barang Milik Negara pada Kantor Wilayah Kementerian Agama Provinsi Sulawesi Utara harus mendapatkan persetujuan terlebih dahulu dari Kementerian Agama yang memerlukan waktu hingga 3 sampai 4 bulan, disebabkan banyaknya satuan kerja Kementerian Agama yang juga melakukan koordinasi dengan Kementerian Agama. Oleh karena itu, Kantor Wilayah Kementerian Agama Provinsi Sulawesi Utara dalam melaksanakan penghapusan Barang Milik Negara dilakukan sekaligus pada saat telah 
terkumpulnya barang-barang yang telah memenuhi persyaratan penghapusan guna terciptanya efisiensi waktu.

\subsection{Saran}

Berdasarkan hasil penelitian dan pembahasan yang telah dilaksanakan, adapun saran yang mungkin dapat dipertimbangkan sebagai masukan untuk dilaksanakan oleh Kantor Wilayah Kementerian Agama Provinsi Sulawesi Utara adalah sebagai berikut:

1. Kantor Wilayah Kementerian Agama Provinsi Sulawesi Utara diharapkan untuk tetap mengikuti peraturan yang berlaku jika terjadi perubahan peraturan di masa yang akan datang, agar supaya sistem dan prosedur penghapusan Barang Milik Negara tetap dapat dijalankan dengan tepat.

2. Kantor Wilayah Kementerian Agama Provinsi Sulawesi diharapkan dapat melaksanakan tindakan penghapusan Barang Milik Negara pada saat telah terkumpulnya beberapa barang saja yang telah memenuhi persyaratan penghapusan Barang Milik Negara, agar tidak terjadi penumpukan barang yang berlebih di gudang tempat penyimpanan barang.

\section{DAFTAR PUSTAKA}

Afrizal. 2016. Metode Penelitian Kualitatif: Sebuah Upaya Mendukung Penggunaan Penelitian Kualitatif Dalam Berbagai Disiplin Ilmu. PT. Rajagrafindo Persada. Jakarta.

Bastian, Indra. 2010. Akuntansi Sektor Publik Suatu Pengantar. Edisi Ketiga. $\quad$ Erlangga. Jakarta.

Mulyadi. 2013. Sistem Akuntansi. Edisi 4. Salemba Empat. Jakarta.

Peraturan Menteri Keuangan Nomor 83/PMK.06/2016 tentang Tata Cara Pelaksanaan Pemusnahan dan Penghapusan Barang Milik Negara.

Peraturan Pemerintah Nomor 60 Tahun 2008 tentang Sistem Pengendalian Intern Pemerintah.

Peraturan Pemerintah Nomor 27 Tahun 2014 tentang Pengelolaan Barang Milik Negara/Daerah.

Peraturan Pemerintah Nomor 71 Tahun 2010 tentang Standar Akuntansi Pemerintahan.

Rodliya, Annisa Robbi. 2015. Tinjauan Atas Sistem Penghapusan Aktiva Tetap Barang Milik Negara (BMN) Pada Direktorat Sarana Dan Prasarana Institut Teknologi Bandung. Skripsi. Universitas Komputer Indonesia. Bandung.

Sailendra, Annie. 2015. Langkah-Langkah Praktis Membuat SOP. Trans Idea Publishing. Yogyakarta.

Sugiyono. 2014. Metode Penelitian Kuantitatif, Kualitatif dan R\&D. Alfabeta. Bandung. Undang-Undang Republik Indonesia Nomor 17 Tahun 2003 tentang Keuangan Negara. 